\title{
THE ANNUAL MEETING OF THE SOCIETY
}

$\mathbf{D}^{\mathrm{o}}$ OUG GILROY, who lives on R.R. 2, north of Regina, was the unanimous choice for president at the third annual meeting of the Society which was held in the auditorium of the Provincial museum of Natural History, October 26. Readers of the BLUE JAY are already acquainted with Mr. Gilroy, and know him as an ardent naturalist and photographer. His illustrated lectures which are now so frequently given in Regina and the surrounding area are being received with enthusiasm and have added his name permanently to the growing list of Saskatchewan's outstanding nature enthusiasts.

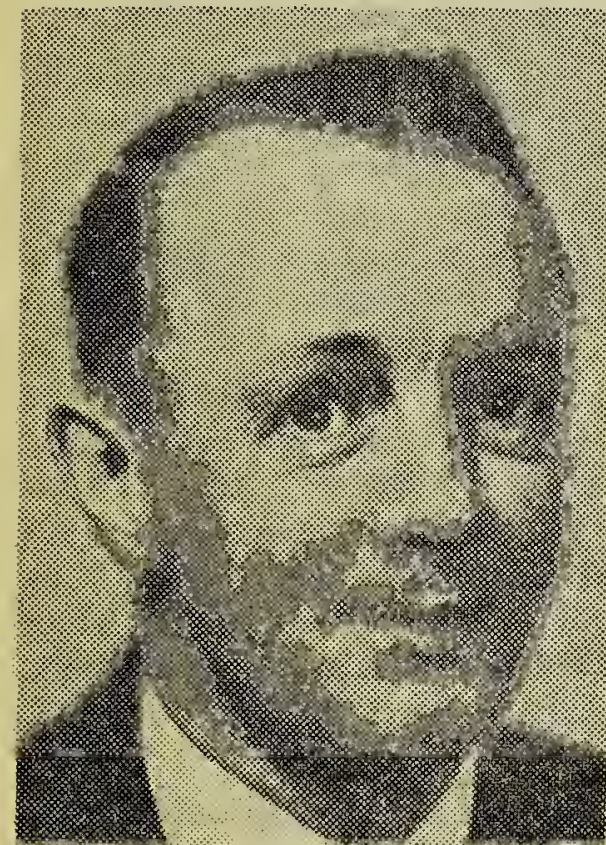

\section{Retiring President Cliff Shaw}

For years, the retiring president, Cliff Shaw has been a tower of strength not only to this Society, but as President of the Yorkton $\mathrm{Natura}$ ? History Society. Not only is he a nature phot og r a pher and writer but has a wide knowledge of the insect life, the flowers and the birds of this province. As immediate past president his advice and help will be constantly sought for and willingly given.

The other new officers elected are shown on the back cover of this issue.

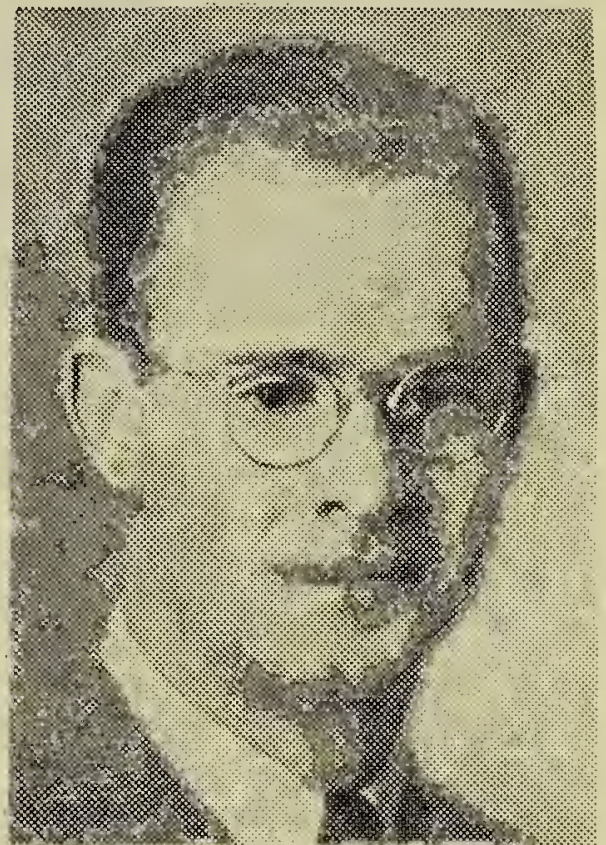

President Doug Gilroy

Due to the late harvest and bad roads many delegates were unable to attend.

Dr. Stuart Houston, Yorkton, who is becoming a widely known naturalist, in his address, discussed in most illuminating fashion, with his own slioes and bird traps, "Waterfowl Conservation and Eird Banding." One pertinent observation: "Never shoot a hawk you can get close enough to shoot at."

Mr. A. J. Hudson, in his archaeology address posed many questions re the first appearance of man here and described some of the thrilling finds while digging in Byzant Creek, near his farm at Mortlach.

Mr. Lloyd Peterson, Indian Head Entomologist, with help of slides described the insects that afflict the prairie Box Elder, American Elm and Green Ash.

Mr. D. R. Robinson, from the University Extension Service, urged growing of fruit-bearing trees for food, and evergreens for shelter and for beauty.

Members were encouraged by Mr. Carmichael's financial and membelship report (844 members). They complimerited him, too, on the well balanced issues of scientific and amateur nature observations.

Fred G. Bard, Lloyd Carmichael and Fred Robinson entertained with interesting slides and commentaries.

Resolutions passed dealt with the Annual Bird Count, a Saturday annual meeting for next year and appreciation of the provincial museum and work done by its director, Fred Bard. 